\title{
Design of Backpack Sprayer with Electrical Pumping System Using Quality Function Development Approach to Optimize the Agricultural Facility
}

\author{
Hernawa Maulana ${ }^{1}$, Anna Nur Nazilah Chamim ${ }^{1}$, Kunnu Purwanto ${ }^{1}$, Ramadoni Syahputra ${ }^{*}$, and \\ Teguh Iman Prasetyo ${ }^{2}$ \\ ${ }^{1}$ Department of Electrical Engineering, Universitas Muhammadiyah Yogyakarta \\ Jl. Lingkar Selatan, Tamantirto, Kasihan, Yogyakarta, Indonesia \\ ${ }^{2}$ Production on the Job Trainer and Competence Assessor, Petroleum Development Oman \\ Muscat, Sultanate of Oman \\ *Corresponding author, e-mail: ramadoni@ugm.ac.id
}

\begin{abstract}
This paper presents an electric back sprayer based on the attributes required by sprayer users with the Quality Function Deployment (QFD) methodology by optimizing sprayers owned by farmers. In agriculture, the process of crop management and care and pest control is carried out routinely to obtain optimal results. The technical implementation of these efforts is carried out through soil and air media by spraying the plant organs. To keep the pressure and spray results stable, continuous pumping is required. This resulted in certainly more energy needed. Based on the results of research on farmers using a sprayer, the type that is widely used is the type of back sprayer. However, in the use of back type sprayers, farmers still experience problems. Problems encountered in using a back sprayer will be reviewed and overcome by developing a sprayer based on the wishes of the farmer. The design of the back sprayer using the Quality Function Deployment (QFD) method is more appropriate to be used in determining the attributes of the development of a back sprayer following the wishes of the fertilizer sprayer user. The resulting sprayer design is expected to be able to overcome the weaknesses in the back sprayer without having to procure a new sprayer, where the problem of the non-constant pressure level in pumping can be overcome.
\end{abstract}

Keywords: Electric back sprayer, Quality Function Deployment (QFD), Optimization

\section{Introduction}

Indonesia is an agrarian country and most of its population earns a living as farmers. In agriculture, the process of crop management and care and pest control is carried out routinely to obtain optimal results. The technical implementation of these efforts is carried out through soil and air media by spraying the plant organs. To spray the crops farmers usually use agricultural equipment, namely sprayers.

Sprayers that are commonly used by farmers in Indonesia are of three types, namely back sprayers, motor sprayers, and electric sprayers. The back sprayer is widely used by farmers because the price is still affordable and the lightest weight, but the spray produced is not effective and the sprayer component is easily damaged. Besides, because pumping is done manually this causes the resulting spray pressure cannot be constant.

To keep the pressure and spray results stable, continuous pumping is required. This resulted in certainly more energy needed. The other type of sprayer is a motor sprayer that uses a 2 stroke engine as a pump drive [1]. This type of sprayer can work in a broad scope in a relatively short time. However, the price and maintenance is relatively expensive, heavier and is not suitable for young plants. Besides, there is also an electric sprayer that 
is driven by a DC pump with a power source in the form of a battery. Judging from the price of this type of sprayer is lighter than a motor sprayer.

Based on the results of research on farmers using a sprayer, the type that is widely used is the type of back sprayer [2]. However, in the use of back type sprayers, farmers still experience problems. Problems encountered in using a back sprayer will be reviewed and overcome by developing a sprayer based on the wishes of the farmer. The design of the back sprayer using the Quality Function Deployment (QFD) method is more appropriate to be used in determining the attributes of the development of a back sprayer following the wishes of the fertilizer sprayer user (farmer) [3]. The resulting sprayer design is expected to be able to overcome the weaknesses in the back sprayer without having to procure a new sprayer, where the problem of the non-constant pressure level in pumping can be overcome.

The use of a back sprayer is evenly distributed among farmers, but the instability of the resulting pressure value causes the spraying results to be suboptimal. The existence of an electric sprayer can be a solution to these problems, but the device was previously abandoned. Therefore we need a design of a sprayer with an electric pumping system while still using a sprayer that is owned by the farmers so that the existing equipment can still be used [4].

The purpose of this research is to design and build an electric back sprayer based on the attributes required by sprayer users with the Quality Function Deployment (QFD) methodology by optimizing sprayers owned by farmers. With the design of an electric back sprayer, it is expected to be able to maximize the use of a back sprayer owned by farmers, as well as minimize the workload in the spraying process. Therefore, the procurement of spraying equipment can only be diverted for other purposes.

\section{Literature Study}

\section{II.1 Study in Designing of Sprayers}

Utomo (2013) in his thesis entitled "Design and Manufacture of Electric Fertilizer Sprayers" make auxiliary equipment in agriculture by producing tools in the form of electric sprayers. The design methodology used is the Theory of Resheniya Izobretatelskikh Zadatch (TRIZ) method. The results of the study were sprayers that were pumped with power sources derived from electrical energy.
Furthermore Priyatmoko et al (2015) in the article entitled "Semi-Automatic Sprayer: Innovation Carry Free and Energy Saving Sprayer" designed a sprayer with a push model, where farmers stayed pushing the sprayer without having to be burdened carrying a sprayer. The method used in the form of field observations. The results of this study in the form of a two-wheel thrust sprayer following the embankment character of vegetable crops.

\section{II.2 Components of a Sprayers}

Sprayers for agricultural purposes are known as 3 types of sprayers, namely back sprayers, machine sprayers, and electric sprayers. Back sprayer or also known as knapsack sprayer. This sprayer is widely used by rice farmers, farmer farmers and plantation farmers.

The working principle of the back sprayer is the liquid in the storage tank will be removed as a result of the process of air pressure that comes from pumping movements on the pump lever. Then the liquid will be released through the valve to the nozzle, then from the nozzle will spray into the target area of the spray. To keep the pressure in the tank stable, pumping must be done often.

The following are the specifications of one of the sprayers commonly used by farmers.

Tank capacity: 15 liters

Spray pressure: $2-6 \mathrm{~kg} / \mathrm{cm} 2$

Tank length: $350 \mathrm{~mm}$

Tank width: $235 \mathrm{~mm}$

Tank height: $530 \mathrm{~mm}$

Sprayer empty weight: $4.2 \mathrm{Kg}$

Sprayer full weight: $18.2 \mathrm{~kg}$

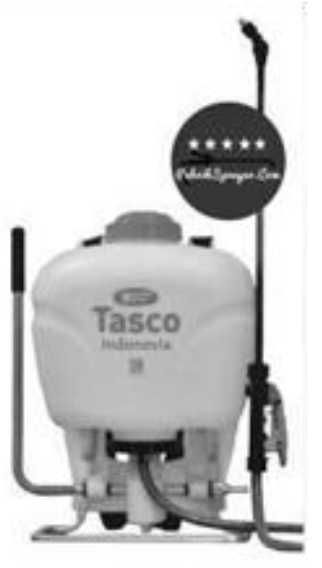

Fig. 1. Back sprayer type

The back type sprayer consists of three main parts namely the tank, pump unit, and pulverizer unit, as can be seen in Figure 1. The tank serves to collect the liquid to be applied. Most of these 
sprayers have a tank capacity of 14-15 liters. In general, there are two kinds of pump units namely the type of suction pump and pump type press. The pulverizer unit consists of three parts, namely the hose, the spraying barrel, and the nozzle. The length of the spray hose is an average of 1 meter, it depends on the manufacturer's brand that produces it. At the other end attached to the handle complete with spray taps. The length of the throwing barrel is $45-50 \mathrm{~cm}$. The spray barrel is usually made of mixed metal, although some are given a layer of the crank on the outside. Society, in general, refers to this section as a sprayer or nozzle. There are two types of nozzle types namely single nozzle and double nozzle.

The motor type sprayer uses a 2 stroke engine as the pump driving force, as seen in Figure 2. The specifications are as follows,

Tank capacity: 20 liters

Fuel capacity: 0.75 liters

Fuel: 2T oil mixed gasoline

Brand: Tosca

Cylinder: $26 \mathrm{cc}$

The engine capacity of $1.8 \mathrm{HP}$

Pressure produced: 5 - $30 \mathrm{~kg} / \mathrm{cm} 2$

Output Volume 1.5 - 7.4 liters per minute

Dimensions: 450 × 330 x $600 \mathrm{~mm}$

Stater: recoil (pulled)

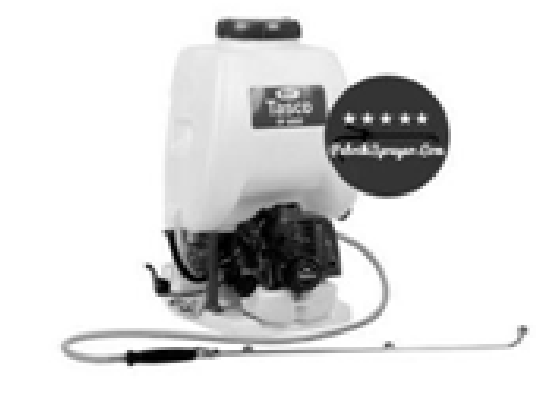

Fig. 2. Motor sprayer type

In electric type sprayers, spraying is done by an electric pump. The machine can be operated with an electric power source that has been stored in the accumulator (battery). The mechanism of using an electric sprayer does not require the pumping process as does the semi-automatic manual sprayer, so the user only needs to activate a switch that disconnects and connects the electric current from the battery to the pump, as seen in Figure 3. Part of the electric sprayer consists of a water pump equipped with an electric motor and a battery. The electric sprayer has a pumping unit that functions to drain the liquid automatically. This pump is a type of centrifugal pump with a power of 24.8 Watt with a maximum pressure of 4.8 bar, the pump display can be seen in Figure 4.

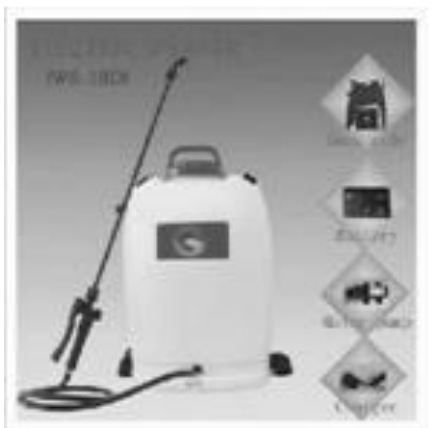

Fig. 3. Electric sprayer type

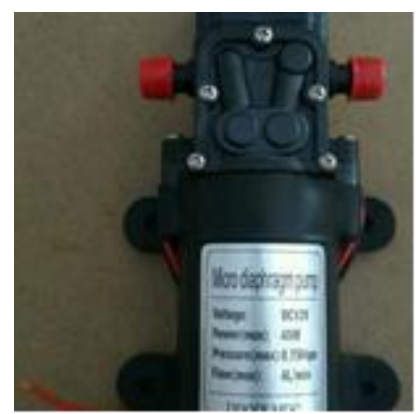

Fig. 4. Water pump of electric sprayer type

The working mechanism of the pump is connected to a battery that allows an energy supply that can move the water pump. The specifications of the battery used have a voltage of $12 \mathrm{~V}, \mathrm{DC}$ current, the weight of $1 \mathrm{~kg}$ and $4 \mathrm{Ah}$.

\section{Methodology}

\section{III.1 Quality Function Deployment Method}

The Quality Function Deployment (QFD) method was created by a Japanese professor named Yoji Akao in the late 1980s. QFD was created to design the process of making a product or service based on customer needs, as seen in Figure 5. The QFD method according to Lou Cohen has staged in the planning and development of the matrix namely:

1) House of Quality Planning Matrix: consists of customer needs, technical requirements, corelationships, relationships, customer competitive evaluations, competitive technical assessments, and targets.

2) Part Deployment Matrix: commonly called a second home.

3) Matrix Process Design (Process Planing): commonly referred to as the third house.

4) Manufacturing Planning Matrix: commonly called the fourth house. 


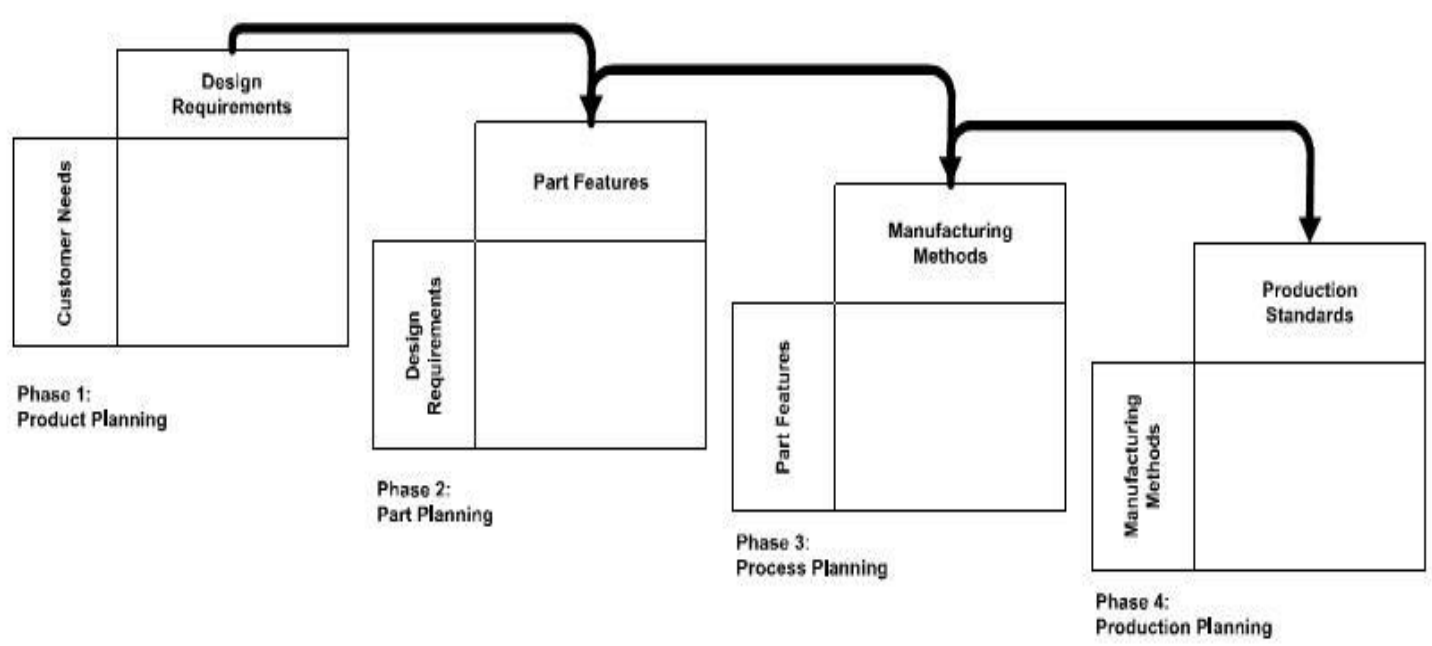

Fig. 5. Quality Function Deployment (QFD) method

\section{2 Product Planning Matrix}

The steps are taken in the process of making a product planning matrix are as follows:

1. Consumer Ratings

User satisfaction cannot be measured directly through subjective measurements but must be assessed as something abstract in the form of certain indicators.

\section{Making Questionnaire}

With the design of a back sprayer design with an electric pumping system, we can find out the user's opinion in this case farmers in terms of weaknesses and strengths of the products produced.

3. Survey

An effective way to do a survey is through direct interviews. The tool used is the same as a questionnaire only filled by field officers who ask respondents in this case farmers using a sprayer.

4. Making a Checklist

Checklists are a common way of determining category assessment methods that can be modified so that different weights can be applied to sentences or words.

5. Making the House of Quality Matrix.

House of Quality (HOQ) is the first house from QFD development. At the House of Quality, there is information about WHATs in the form of customer requirements or the voice of customers, HOWs in the form of technical requirements, competitive assessment relationship matrix.

6. Filling in the House of Quality Matrix

The stage before completing the House of Quality matrix is the making of a planning matrix consisting of the level of consumer interest and the level of customer satisfaction.

\section{Results and Discussion}

The general description of the electrical sprayer system block diagram in this study is shown in Figure 6. Next in Figure 7 is shown the DC pump switching diagram block in the disconnected switch condition. The DC pump switching diagram of the connected switch condition is shown in Figure 8.

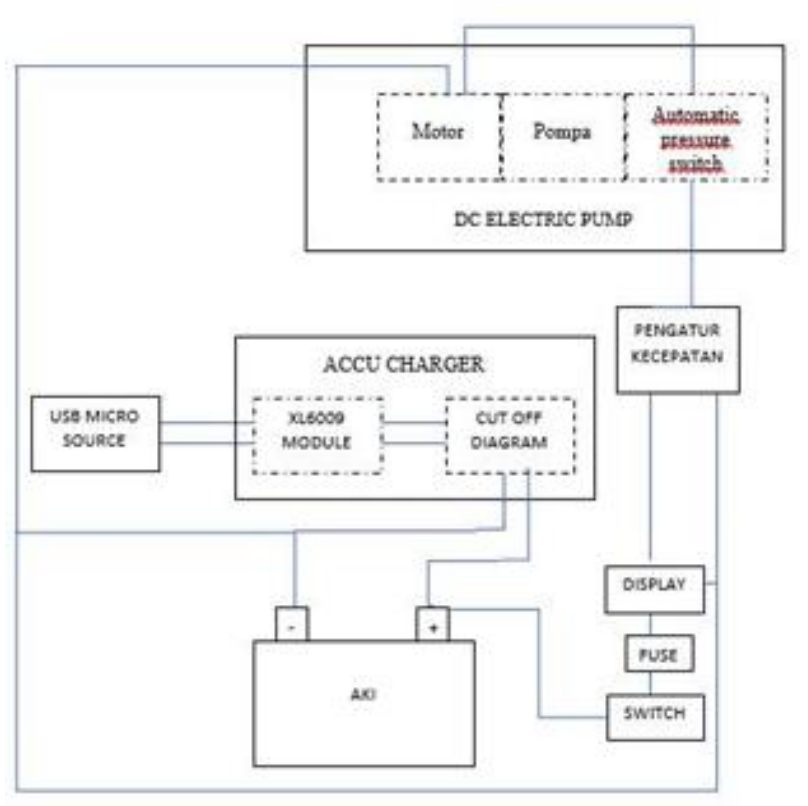

Fig. 6. The complete electrical sprayer system block diagram

The process of recharging the battery in this study uses the XL6009 module which functions to change the voltage from the micro USB input both from the cell phone charger, power bank or other resources.

The old technical calculation of the battery with 12 Volt voltage specifications and 4Ah capacity, 
can backup the load is as follows:

Pump power $=24.8 \mathrm{Watt}$

Electric current on the battery (24.8 Watt / 12

Volt $)=2.066$ Amperes

Usage Time (12 Ah / 2,066 Ampere) $=5.808$

hours - Battery deficiency value $=0.5$ hours

Estimated battery timeout (5.808 Hours - 0.5

Hours) $=5.308$ hours

The optimal charging voltage on the 12 Volt battery ranges from $110 \%$ to $115 \%$ of the nominal battery voltage. So we get the optimal range of charging voltage values:

$110 \% \times 12$ Volts $=13.2$ Volts

$115 \% \times 12$ Volts $=13.8$ Volts

In testing the equipment made in this study, the value of the charging voltage is $\pm 13.52 \mathrm{~V}$, as seen in Figure 9.

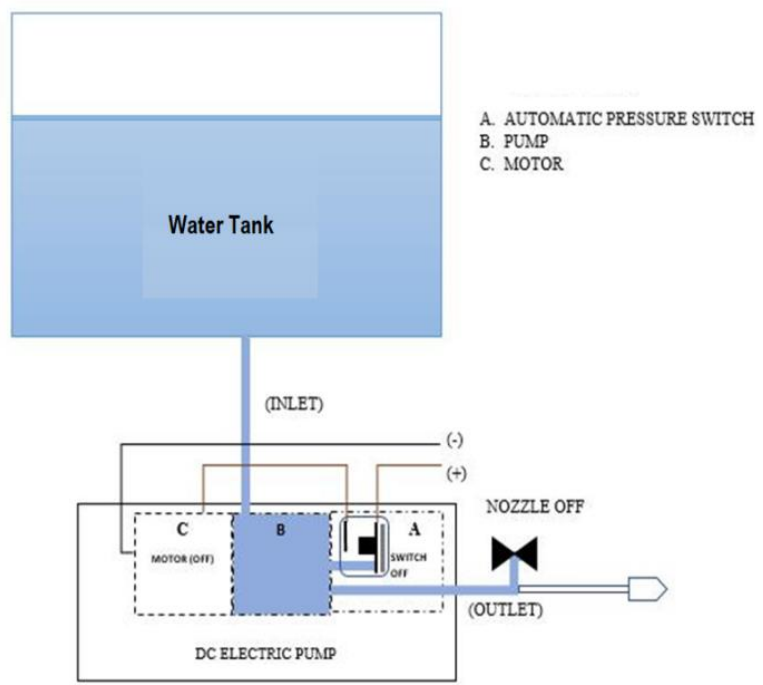

Fig. 7. DC pump switching diagram block in the disconnected switch condition

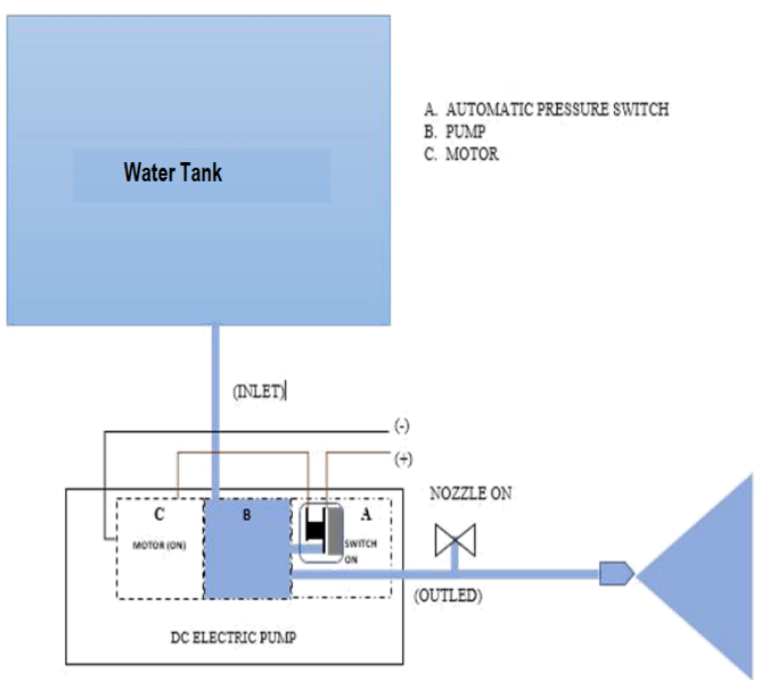

Fig. 8. DC pump switching diagram block in the connected switch condition

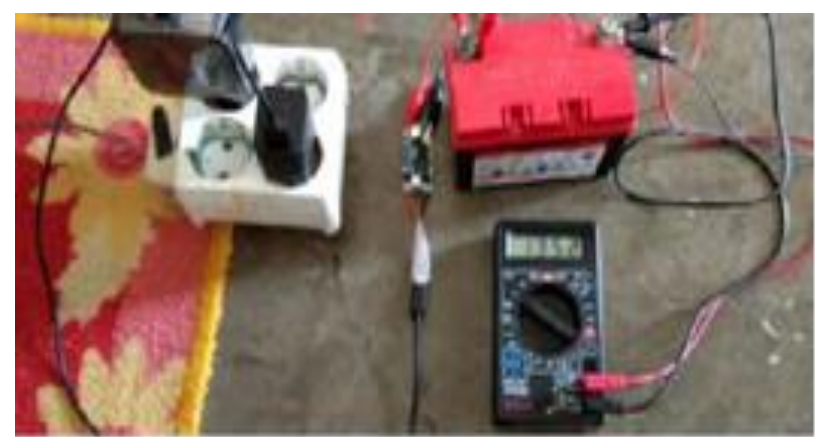

Fig. 9. Voltage measurement of charging process

The results of the sprayer test are completely summarized in a table as shown in Table 1.

TABLE I

THE RESUlts OF THE SPRAYER TEST

\begin{tabular}{ll}
\hline \hline \multicolumn{1}{c}{ Examination criterion } & $\begin{array}{l}\text { The results of the sprayer } \\
\text { test }\end{array}$ \\
\hline $\begin{array}{l}\text { Weight less than } 10 \mathrm{~kg} \\
\text { Costs less than IDR } 550,000\end{array}$ & $\begin{array}{l}8.5 \mathrm{~kg} \\
\text { IDR } 536,000\end{array}$ \\
$\begin{array}{l}\text { Spray range of more than } 2 \mathrm{~m} \\
\text { The duration of use is more }\end{array}$ & $\begin{array}{l}3 \text { meters } \\
5 \text { hours } 18 \text { minutes and } 48 \\
\text { than } 1 \text { hour }\end{array}$ \\
$\begin{array}{l}\text { Power source from } 12 \text { volt } \\
\text { sattery }\end{array}$ & 12 volt 4 Ah \\
The spray rate is stable & 1.5 liters per minute \\
\hline \hline
\end{tabular}

\section{Conclusion}

Based on the research results of the electrical sprayer design the conclusion is in the form of an electrical sprayer design that can work optimally with a 12-volt battery, $4 \mathrm{Ah}$, producing a constant spray of 1.5 Liters per minute for 5 hours 18 minutes and 48 seconds. This design tool can reach a distance of 3 meters and can be operated both electrically and manually. The test results also showed that the sprayer results of this study were able to show stable performance for long-term use.

\section{References}

[1] Grande, J. (2012). Don't Overlook Backpack Sprayers. New Jersey: Snyder Research Farm.

[2] Meidasari, D.S., Bachtiar, I. (2015). Usulan Desain Produk Sepatu Pantofel Wanita dengan Pendekatan Quality Function. Deployment (QFD) di CV Madas. http://karyailmiah.unisba.ac.id/index.php /industri/article/download/307/pdf.

[3] Cohen, L. (1995). Quality function deployment : How to make QFD work of you. New York: Wesley Publishing Company.

[4] Guilford, J.P. (1956). Fundamental Statistics in Psychology and Education. McGraw-Hill Book Co. Inc., New York. 


\section{Authors' information}

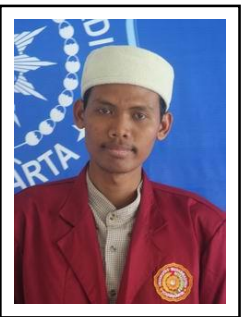

Hernawa Maulana received B.Sc. degree from Department of Electrical Engineering, Universitas Muhammadiyah Muhammadiyah Yogyakarta, Yogyakarta, Indonesia.

His research interests are in operation of power distribution system and power distribution system planning.

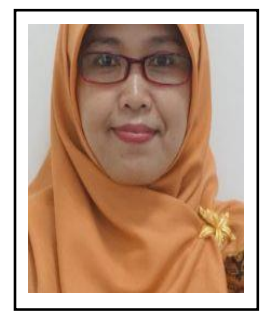

Anna Nur Nazilah Chamim obtained her B. Eng in Electrical Engineering from Universitas Muhammadiyah Yogyakarta, Indonesia. Her Master study was done at 2015 at the Electrical Engineering, Universitas Gadjah Mada, Indonesia. She currently is a lecture in department of Electrical engineering, Universitas Muhammadiyah Yogyakarta. Her main research interest is in electronics, telecommunication, and signal processing.

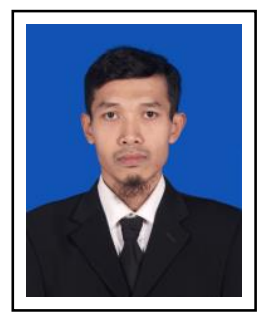

Kunnu Purwanto is a lecturer and researcher in Electrical Engineering Department, Faculty of Engineering, Universitas Muhammadiyah Yogyakarta (UMY). He received bachelor degree from UMY and M.Eng degree from Universitas Gadjah Mada (UGM). Kunnu Purwanto is actively involved in national robotic contest and activities as a delegate from UMY. His research interests are in electronics, instrumentation, and control system.

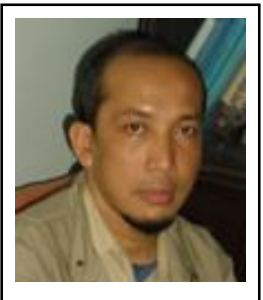

Ramadoni Syahputra received B.Sc. degree from Institut Teknologi Medan in 1998, M.Eng. degree from Department of Electrical Engineering, Universitas Gadjah Mada, Yogyakarta, Indonesia in 2002, and Ph.D degree at the Department of Electrical Engineering, Faculty of Industrial Technology, Institut Teknologi Sepuluh Nopember, Surabaya, Indonesia in 2015.

Dr. Ramadoni Syahputra is a Lecturer in Department of Electrical Engineering, Faculty of Engineering, Universitas Muhammadiyah Yogyakarta, Indonesia. His research interests are in computational of power system, artificial intelligence in power system, power system control, the application of fuzzy logic in power system, optimization, distributed energy resources, and renewable energy.

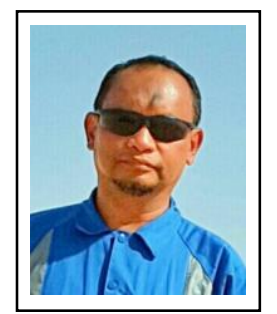

Teguh Iman Prasetyo hold a bachelor degree in 2000 from Electrical Engineering Department, Universitas Muhammadiyah Yogyakarta, Indonesia. Mr. Teguh Iman Prasetyo is currently a professional in Production on the Job Trainer and Competence Assessor, Petroleum Development Oman, Muscat, Sultanate of Oman. His main research interest is in control system and distributed control system. 